University of Zurich

Department of Economics

Working Paper Series

ISSN 1664-7041 (print)

ISSN 1664-705X (online)

Working Paper No. 325

\title{
Bank lending, financial frictions, and inside money creation
}

Lukas Altermatt

May 2019 


\title{
Bank lending, financial frictions, and inside money creation*
}

\author{
Lukas Altermatt ${ }^{\dagger}$
}

May 28, 2019

\begin{abstract}
I build a general equilibrium model of the transmission of monetary policy on bank lending. Bank lending is done by individual banks that face random investment opportunities by creating inside money. Banks are subject to a reserve requirement and have access to the interbank money market. The model shows that lowering the money market rate relative to the inflation rate reduces investment and welfare. This is because the money market is an outside option for banks that face bad investment opportunities. Reducing the money market rate lowers the value of this outside option, which in turn reduces banks' willingness to acquire reserves ex-ante. This leads to less aggregate reserves, which reduces the banking system's ability to grant credit.
\end{abstract}

Keywords: Monetary policy transmission, open market operations, channel system, interest rate pass-through

JEL codes: E4, E5

${ }^{*}$ I am grateful to my adviser Aleksander Berentsen for his useful comments that greatly improved the paper and to my colleagues Mohammed Ait Lahcen and Romina Ruprecht for many insightful discussions. I thank Randall Wright, Ed Nosal, Cyril Monnet, Pedro Gomis-Porqueras, Christian Wipf, Lukas Voellmy, Ewelina Laskowska, Florian Boeser, and seminar participants at the University of Bern and the Gerzensee Alumni Conference 2018 for valuable comments and suggestions.

${ }^{\dagger}$ University of Wisconsin-Madison and University of Basel. lu.altermatt@gmail.com 


\section{Introduction}

One of the key roles of monetary policy is to ensure that bank lending can be done efficiently. In fact, the bank lending channel is one of the main channels to consider for the transmission of monetary policy to the real economy. The financial crisis of 2007-2009 and its aftermath has shown that several frictions can hinder the transmission from monetary policy to bank lending, and that the effect of these frictions on monetary policy transmission are as of yet not very well understood. In this paper, I explicitly model the transmission channel of monetary policy to bank lending. The paper shows that this explicit modeling makes several frictions inside and outside the banking system emerge endogenously. Frictions inside the banking system are stemming from limited commitment on the money market, which makes collateral necessary to obtain loans, and the fact that it takes time to raise additional equity and deposits. Frictions outside the banking system stem from bargaining between banks and entrepreneurs. Furthermore, controlling monetary aggregates is difficult for the central bank because banks have the ability to create inside money. This paper shows that these frictions affect monetary policy transmission and lead to some surprising effects that go against the conventional wisdom.

Ceteris paribus, lowering the equilibrium lending rate that banks offer to entrepreneurs should increase bank lending and thus investment. Since central banks cannot control lending rates directly, they have to rely on some intermediate targets. Specifically, they can directly affect other interest rates in the economy such as the bond interest rate and the money market interest rate. According to the conventional wisdom, lowering the money market rate will increase bank lending, as a lower money market rate makes refinancing for banks cheaper. In this paper, the monetary authority has four instruments through which it can affect the money market rate: The channel system, open market operations, the reserve requirement, and the money growth rate. However, due to the frictions inside the banking system, a lower money market interest rate has varying effects on bank lending, depending on which tool was used to lower the rate. In fact, only when the money market rate is lowered via the money growth rate, bank lending will increase. When it is lowered via a channel system, the reserve requirement, or open market asset purchases, bank lending decreases on aggregate. The reason for this surprising result is that all policies also affect banks' willingness to acquire reserves ex-ante. If the money market rate is lowered relative to the inflation rate, acquiring reserves ex-ante becomes less attractive. But if reserve acquisitions are reduced, a larger share of banks ends up facing higher refinancing costs due to financial frictions. Because lowering the money growth rate lowers both the inflation rate and the money market rate, it has positive effects on output. Conversely, lowering the money market rate via open market 
purchases, or changes in the channel system or the reserve requirement, does not affect inflation, and thus reduces aggregate investment and output.

The model in this paper builds on the framework of Berentsen et al. (2014). Banks are matched with entrepreneurs that get random investment opportunities. The entrepreneurs need loans from the banks to acquire capital, and the banks can finance these loans by creating deposits (inside money). Entrepreneurs use these deposits to pay capital suppliers, and because capital suppliers are uniformly distributed across banks, all banks receive the average amount of deposits after these trades occur. In creating deposits, banks are constrained by a reserve requirement which they have to fulfill at the end of each period. Banks have to hold some fraction $\delta$ of their short-term liabilities as reserves. Banks can purchase reserves ex ante (before realization of the investment opportunities) by raising equity, or they can borrow them ex post (after realization of the investment opportunities) on the interbank money market against collateral. In equilibrium, all banks acquire the same amount of collateral and reserves ex ante, but ex post, banks with bad investment opportunities lend excess reserves on the money market while banks with good investment opportunities borrow. This friction leads to nonlinearities in the lending behavior of banks: Banks that are net lenders on the money market face as an opportunity cost of investment the interest rate on the money market. Banks that are net borrowers, however, face a higher opportunity cost, because to invest more, they need to acquire not only the funds they invest but also additional reserves to fulfill the reserve requirement, so they pay the money market interest rate on $\frac{1}{1-\delta}$ times their additional investment. On top of that, those banks with the best lending opportunities cannot fully exploit them as they are collateral constrained on the money market. Due to these varying opportunity costs of investment, marginal returns on investment are not equalized across banks and thus investment is not efficient. Bargaining between banks and entrepreneurs adds another friction. If banks have high bargaining power, it is possible that some banks overinvest, but for moderate bargaining power, all banks invest too little. Banks that are net lenders on the money market invest the most on the margin, while the collateral-constrained banks have the highest marginal return on investment. As these are the banks facing the best investment opportunities, the best projects are underfunded in equilibrium. Banks that are not collateral constrained, but net borrowers on the money market have a higher marginal return on investment than net lenders. Due to this market structure, any monetary policy tool affects bank lending in two main ways: Directly by changing the money market interest rate, which lowers opportunity costs of investment for all banks that are not collateral-constrained and thus increases their lending, and indirectly by changing the shares of banks that fall into the three categories. Increasing the share of net 
lenders on the money market increases aggregate lending, while increasing the share of collateralconstrained banks decreases aggregate lending. An increase in the share of net borrowers on the money market has ambiguous effects, as it depends on which categories' share is reduced instead. The monetary authority has four policy tools at its disposal: (1) It can change the money growth rate by altering the amount of newly-issued currency per period. This policy directly affects the inflation rate in the economy. (2) The monetary authority can alter the amount of collateral available in the economy via open market operations. (3) The monetary authority can alter the reserve requirement by changing $\delta$. (4) The monetary authority operates standing facilities during the money market that allow banks to borrow or deposit reserves against predetermined rates. If these rates offer better conditions than the equilibrium money market rate, the money market rate will change. The choice of these rates is what I refer to as the channel system. As mentioned above, only if the money market rate is lowered via the money growth rate, bank lending will increase. With all the other tools, the indirect effect dominates, i.e., the share of banks that face a low marginal return on investment decreases by so much that aggregate lending decreases. The effect is different for the money growth rate because lowering the money growth rate decreases the nominal money market rate and inflation simultaneously and thus does not affect the real money market interest rate. All other tools lower both the nominal and the real money market rate as they leave inflation unchanged. A lower real money market rate makes acquiring reserves ex-ante less attractive.

The framework presented in this paper is built according to the actual monetary system in Switzerland, and the Eurozone to a lesser extent. This is mainly captured by a centralized money market where collateral is required to receive loans. However, it is straightforward to change some of the specifications in the model in order to resemble other markets.

Related literature. There is a literature that studies the effects of changes in the money market interest rate on banks' actions (see e.g. Berentsen and Monnet (2008) for channel systems, Berentsen et al. (2014) for floor systems, or Berentsen et al. (2015) and Arce et al. (2018) for a comparison of both), but in these papers, some major aspects are missing, such as banks' ability to create inside money by extending credit, and various frictions that arise due to the structure of the interbank market. In this paper, I add these aspects and show how the results are affected by the inclusion of them. This paper can also be seen as an extension of Altermatt (2017). While that paper also has inside money, there is no heterogeneity across banks and therefore no interbank market. 
Regarding financial frictions, Brunnermeier et al. (2012) is a good starting point. The authors cite several studies that show taking into account financial frictions alters the results of standard models drastically. While financial institutions can overcome some frictions, they introduce additional fragility and can destabilize inflation. While most of the studies cited in Brunnermeier et al. (2012) model financial frictions ad-hoc, such frictions arise endogenously in this paper.

Gertler and Karadi (2011) analyze the effects of unconventional monetary policy on financial intermediaries. This is related to my paper as some of the policies studied can be considered unconventional. However, Gertler and Karadi assume differences between private banks and the central bank that should ideally arise endogenously in a model. Bianchi and Bigio (2017) develop a model where banks face idiosyncratic withdrawal risks and can create inside money. While they give the central bank in their model a set of tools to use, they focus mainly on the effect of changes in the inflation rate on banks directly. Piazzesi and Schneider (2018) is another recent paper that attempts to incorporate banking and different interest rates into a macroeconomic model. This paper is also similar to Faure and Gersbach (2017) in the way inside money is created. However, Faure and Gersbach (2017) is a two-period model. Having an infinite horizon allows me to better pin down interest rates and prices and thus find more results. Brunnermeier and Koby (2017) also show that lowering interest rates can sometimes decrease output. However, the mechanism in their model is completely different from the one at work in this paper.

Within the New Monetarist literature, banking was first integrated into the Lagos and Wright (2005) framework by Berentsen et al. (2007). While the focus of the paper was different, the mechanism behind its results is very similar to this paper. Berentsen et al. show that banks are welfare-improving because they allow agents who don't need liquid assets to earn an interest rate on these assets, which in turn increases aggregate liquidity. Here, the money market interest rate serves a similar role for reserves, and lowering it decreases the amount of aggregate reserves in the system.

The first paper in the literature that really tried to capture the role of banking in the transmission mechanism of monetary policy was Williamson (2012). In Williamson's paper, banks had two main roles: First, they provide insurance against liquidity risk akin to Diamond and Dybvig (1983), and second, they serve as monitors of entrepreneurs to allow for more efficient investment. Compared to this paper, Williamson lacks inside money creation and heterogeneity across banks. Another important paper on banking from the New Monetarist literature is Gu et al. (2013), but monetary policy is not studied by the authors. In a recent paper with a somewhat different framework from what I do here, Rocheteau et al. (2018) also show how the pass-through from interest rates to bank 
lending is affected by financial frictions.

Outline. This paper is organized as follows. In Section 2, the model is presented. Section 3 shows the equilibrium and theoretical results. In Section 4, the policy analysis is conducted. Finally, Section 5 concludes.

\section{The model}

Time is discrete and continues forever. Each period is divided into two subperiods that open sequentially. The first subperiod is called the settlement market, and the second subperiod is called the loan market. The economy is populated by a continuum of infinitely lived banks, a continuum of infinitely lived capital producers, and a continuum of two-period lived entrepreneurs, each of measure one. The banks' preferences are given by

$$
\mathbb{E}_{0} \sum_{t=0}^{\infty} \beta^{t}\left(c_{t}-h_{t}\right) .
$$

Equation (1) states that banks get linear utility from consuming $c_{t}$ units of a generic good and linear disutility from working $h_{t}$ hours in period $t^{1}$. Consumption and labor effort both take place in the settlement market, and there is a linear technology that transforms one hour of labor into one unit of the generic good. Future periods are discounted by a factor $\beta \in(0,1)$.

Preferences of capital producers are given by

$$
\mathbb{E}_{0} \sum_{t=0}^{\infty} \beta^{t}\left(c_{t}-k_{t}\right)
$$

so capital producers face a unit linear cost to produce capital $k_{t}$, and they get linear utility from consuming general goods in the settlement market. Capital can be produced during both subperiods, but in equilibrium, it will only be produced during the loan market, as investment occurs also during this subperiod.

A continuum of entrepreneurs is born at the beginning of each settlement market. Each generation of entrepreneurs lives until the end of the next settlement market. During the first settlement

\footnotetext{
${ }^{1}$ There are two possible interpretations for the assumption that banks consume goods and can exert labor effort. The banks can either be assumed to be private bankers, i.e., agents that ultimately care about their consumption, or one can assume that banks are owned by the other agents in the model. Both cases are valid mathematically, as all agents in this model have linear preferences over consumption during the settlement market.
} 
market of an entrepreneur's life, he is randomly matched with a bank. The preferences of an entrepreneur born in period $t$ are given by

$$
\mathbb{E}_{t} \beta c_{t+1},
$$

so entrepreneurs cannot acquire funds during their first settlement market and only care about second-period consumption ${ }^{2}$.

There is a monetary authority that issues fiat money $M_{t}$. The growth rate of fiat money is denoted as $\gamma=\frac{M_{t}}{M_{t-1}}$. New fiat money is issued in the settlement market and distributed via lumpsum transfers $\Delta$ to capital producers. The value of one unit of fiat money in the settlement market of period $t$ is denoted by $\phi$, and the inflation rate is defined as $\phi_{t} / \phi_{t+1}-1=\pi_{t}$. If fiat money is held by a bank, I will interpret it as reserves. The monetary authority sets a reserve requirement $\delta$ that must be fulfilled at the end of the period, i.e. after the loan market closes. Banks have to hold reserves against all short-term liabilities, i.e., against deposits and money market loans. The monetary authority sets two interest rates $i^{L}$ and $i^{D}$, at which banks deposit $\left(i^{D}\right)$ reserves, or borrow $\left(i^{L}\right)$ reserves against collateral during the loan market. These two interest rates are collectively called the channel system. I assume $0 \leq i^{D}<i^{L}$.

The fiscal authority has to finance some spending $g_{t}$ in each period, and can do so by levying lump-sum, per capita taxes $T_{t}$ on capital producers or by issuing one-period bonds. One bond is sold for one unit of fiat money and redeemed for $1+i^{b}$ units of fiat money in the next period, where $i^{b}$ is determined by market clearing. This gives rise to the following government budget constraint:

$$
\phi_{t} B_{t}+T_{t}=\phi_{t}\left(1+i_{t}^{b}\right) B_{t-1}+g_{t}
$$

It is assumed that the government exogenously decides whether to finance its expenditures through debt or taxes, and that it keeps the real quantity of bonds issued fixed over time. $\mathcal{B}_{t}=\phi_{t} B_{t}$ denotes the real quantity of bonds. The fiscal authority takes $\phi_{t}$ as given and issues as many bonds $B_{t}$ as needed to keep $\mathcal{B}_{t}=\mathcal{B} \forall t^{3}$. I define the net real lump-sum tax to capital producers as $\tau_{t}=T_{t}-\Delta_{t}$.

\footnotetext{
${ }^{2}$ While the discount factor $\beta$ does not matter in the maximization problem of entrepreneurs, I include it to make sure all agents have the same discount factor. This might matter in terms of aggregate welfare.

${ }^{3}$ For constant fiat money growth rates, this policy implies bonds grow at the same rate as fiat money, and the bonds-to-money ratio stays constant.
} 
In the following, I will drop time subscripts to ease notation. Parameters without any superscripts are denoting current-period variables; plus $(+)$ or minus $(-)$ superscripts indicate next or previous period's variables, respectively.

\subsection{Loan market}

Banks enter the loan market with reserves $m$ and bonds $b$ accumulated in the settlement market, an equity position of $m+b$, and no further liabilities ${ }^{4}$. At the beginning of the loan market, each entrepreneur receives an investment opportunity with a return $\eta f(k)$ paid off in the next settlement market $^{5}$, where $\eta$ is an i.i.d. random variable with distribution $G(\eta)$ and support $[0, \infty] . f(k)$ is a concave function with $f(0)=0, f^{\prime}(k)>0, f^{\prime \prime}(k)<0$, and $f^{\prime}(0)=\infty$. As entrepreneurs have no funds of their own, they bargain with the bank they are matched with to receive funds in order to buy capital from capital producers.

To finance the investment, banks can create inside money. To do so, they create two balance sheet positions: An asset position $\ell_{\eta}$ that denotes the loan, and a liabilities position $\ell_{\eta}$ that denotes the deposits (inside money) created to finance the loan. Loans have to be repaid in the next settlement market. Deposits can be traded and pay the interest rate $i^{d}$ in the next settlement market. The owner of a deposit can withdraw it at any time to receive fiat money. If withdrawal occurs before the settlement market, the interest rate on deposits is foregone.

The entrepreneur then uses these deposits to buy capital from capital producers. The capital market is perfectly competitive, so to buy some amount of capital $k$, entrepreneurs have to pay

$$
k=\beta \phi^{+}\left(1+i^{d}\right) \ell
$$

So how much capital can be bought with some amount of deposits depends on discounting, next period's price level, and the interest rate on deposits. This is because capital producers use deposits to buy general goods during next period's settlement market, and the amount of general goods they can buy with some amount of deposits depends on these variables. To simplify notation, I use $\kappa$ to denote the price of capital. Thus,

$$
\frac{1}{\kappa}=\beta \phi^{+}\left(1+i^{d}\right)
$$

which implies $\kappa k=\ell$.

\footnotetext{
${ }^{4}$ Throughout this paper, I will be explicit about banks' balance sheet positions; i.e., assets and liabilities are always spelled out explicitly.

${ }^{5}$ The assumption that all loans pay off in the following settlement market stands in for the idea that long-term loans can be sold at fair prices during the settlement market. From the point of view of an individual bank, a loan paying off or being sold at a price that equals its discounted return is equivalent.
} 
Capital producers could also withdraw the deposits they receive and get cash from the bank. However, they will not do so as long as $i^{d} \geq 0$.

Taking the capital pricing as given, An entrepreneur's total surplus can be denoted by $\eta f\left(\frac{\ell_{\eta}}{\kappa}\right)-$ $\phi^{+} \ell_{\eta}$. I assume that banks can extract a share $\theta$ of an entrepreneur's surplus, so if a bank creates the loan $\ell_{\eta}$ in period $t$, it receives $\theta\left(\eta f\left(\frac{\ell_{\eta}}{\kappa}\right)-\phi^{+} \ell_{\eta}\right)+\phi^{+} \ell_{\eta}$ in period $t+1 . \theta\left(f\left(\frac{\ell_{\eta}}{\kappa}\right)-\phi^{+} \ell_{\eta}\right)$ can be interpreted as the interest payment on the loan ${ }^{6}$.

The first-best investment for each entrepreneur is given by

$$
\eta f^{\prime}\left(\frac{\ell_{\eta}}{\kappa}\right)=\frac{1}{\beta}
$$

as this level of investment equates marginal return with the marginal cost to produce capital.

I assume a symmetric equilibrium; i.e., all capital producers produce the same amount of capital. Additionally, I assume that capital producers are uniformly distributed across banks ${ }^{7}$. This ensures that at the end of the period, deposits are evenly distributed among banks. Thus, each banks' deposit position at the end of the period is

$$
d=\int_{0}^{\infty} \ell_{\eta} \mathrm{d} F(\eta) .
$$

If a deposit is traded from one bank to another, the bank that receives the deposit simultaneously grants a money market loan to the bank the deposit was transferred from to settle the trade. The money market is collateralized, i.e., a bank needs to hold collateral (bonds) to receive loans on the money market. Banks pay (earn) the interest rate $i^{M}$ on money market loans they borrow (lend) in the following settlement market. A banks' net money market position after trading of deposits has occurred is equal to $d-\ell_{\eta}$. If $d-\ell_{\eta}>0$ for a specific bank, this bank is a net lender on the money market, and the total size of its balance sheet is $m+b+d$. If $d-\ell_{\eta}<0$ for a specific bank, the bank is a net debtor on the money market, and the total size of its balance sheet is equal to $m+b+\ell_{\eta}$. As all banks receive the same amount of deposits, all differences in the amount of total short-term liabilities (deposits and money market loans) of a bank entirely stem from the amount of net borrowing on the money market, and thus on the size of the loan created.

\footnotetext{
${ }^{6}$ Note that I assume throughout that an entrepreneur cannot get credit from capital producers directly. This is sensible, as entrepreneurs have no incentive to pay back loans. Thus, the underlying assumption is that banks are able to enforce repayments from entrepreneurs.

${ }^{7}$ The underlying assumption here is that capital producers open deposit accounts at banks during the settlement market. They open an account with the bank that offers the highest interest rate on deposits, but since in equilibrium, all banks will offer the same interest rate, capital producers are indifferent about which bank they should choose.
} 
Thus, for banks that are net borrowers on the money market, the amount of short-term liabilities is increasing in the loan the bank granted. To fulfill the reserve requirement, banks with more short-term liabilities need more reserves, and thus banks that already are net borrowers on the money market borrow reserves $r_{\eta}$ from banks that are net lenders such that

$$
m+r_{\eta} \geq \delta\left(\ell_{\eta}+r_{\eta}\right)
$$

On the other hand, banks that are net lenders can lend additional reserves until

$$
m+r_{\eta} \geq \delta d
$$

binds (Note that $r_{\eta}<0$ for a bank that is a net lender). As can clearly be seen from the two constraints above, the reserve requirement affects net lenders differently than net borrowers. This is because for a net lender, lending out reserves does not affect the amount of short-term liabilities, while for net borrowers, borrowing reserves increases short-term liabilities, which means they need to borrow $\frac{1}{1-\delta}$ times the amount that they were originally short on reserves.

Instead of using the money market to lend out or borrow reserves, banks can also borrow or deposit reserves with the monetary authority. To borrow reserves from the monetary authority, banks also need collateral. In equilibrium, this ensures that the money market rate is always inside the channel, i.e., $i^{D} \leq i^{M} \leq i^{L}$. I denote the money market rate that would prevail without standing facilities as $\iota^{M}$. If $i^{D}<\iota^{M}<i^{L}$, all banks strictly prefer to borrow or lend on the money market, and the channel system has no effect as $i^{M}=\iota^{M}$. If $i^{D} \geq \iota^{M}\left(\iota^{M} \geq i^{L}\right), i^{M}=i^{D}\left(i^{M}=i^{L}\right)$, so banks are indifferent about lending out on the money market or depositing at the standing facility (borrowing on the money market or at the standing facility).

\begin{tabular}{c|c} 
assets & liabilities \\
\hline $\begin{array}{c}\text { Reserves } \\
m-\ell_{\eta}-x_{\eta}\end{array}$ & \\
\hline Bonds & Equity \\
$b$ & $m+b$ \\
Money market & Deposits \\
$x_{\eta}$ & $d$ \\
Loans & \\
$\ell_{\eta}$ &
\end{tabular}

Figure 1: Balance sheet of a bank that is a net lender on the money market. 


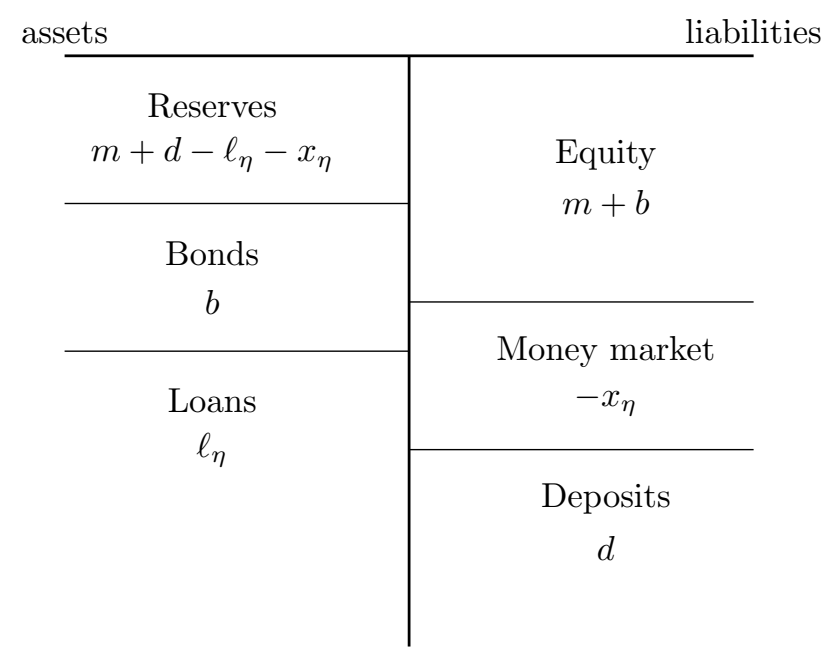

Figure 2: Balance sheet of a bank that is a net borrower on the money market.

Because the reserve requirement affects banks differently depending on whether they are net lenders or borrowers on the money market, it is helpful to introduce new variables for the money market positions. Therefore, I define the net money market position as

$$
x_{\eta}=d-\ell_{\eta}-r_{\eta}
$$

So for a bank that is a net lender (borrower) on the money market, $x_{\eta}>0\left(x_{\eta}<0\right)$, and reserves are then denoted by $m+d-\ell_{\eta}-x_{\eta}$ for all banks. For net lenders, the reserve requirement constraint is now given by

$$
m-\ell_{\eta} \geq x_{\eta}-(1-\delta) d
$$

and for net borrowers, it is

$$
m-\ell_{\eta} \geq(1-\delta) x_{\eta}-(1-\delta) d
$$

The collateral constraint is only relevant for borrowers on the money market and is given by

$$
-x_{\eta} \leq b
$$

Figures 1 and 2 show the balance sheets of banks that are net lenders or borrowers on the money market, respectively, at the end of the period. 
Now, I can formulate the banks' problem in the loan market as

$$
\begin{aligned}
V^{L}(m, b) & =\max _{\ell_{\eta}, x_{\eta}} \beta V^{S}\left(m+d-\ell_{\eta}-x_{\eta}, b\right) \\
\text { s.t. } & m-\ell_{\eta} \leq(1-\delta I) x_{\eta}-(1-\delta) d \quad \text { with } I=0 \text { if } x_{\eta} \geq 0, I=1 \text { otherwise } \\
& -x_{\eta} \leq b .
\end{aligned}
$$

Banks decide on the value of loans to grant and on their net money market condition, subject to fulfilling the reserve requirement and collateral constraints. Then, banks continue to the settlement market.

\subsection{Settlement market}

Banks enter the settlement market with the balance sheets depicted in Figures 1 and 2. After all these positions are settled, banks choose consumption and how many bonds and reserves to acquire. Thus, their value function is

$$
\begin{gathered}
V^{S}\left(m+d-\ell_{\eta}-x_{\eta}, b\right)=\max _{m^{\prime}, b^{\prime}, c, h} c-h+\mathbb{E}\left[V^{L}\left(m^{\prime}, b^{\prime}\right)\right] \\
\text { s.t. } \phi\left(m^{\prime}+b^{\prime}\right)+c=h+\phi m+\phi\left(1+i^{b}\right) b-\phi i^{d} d+\phi i^{M} x_{\eta}+\theta\left(\eta f\left(\frac{\ell_{\eta}}{\kappa^{-}}\right)-\phi \ell_{\eta}\right) .
\end{gathered}
$$

Banks entering the settlement market with reserves $m+d-\ell_{\eta}-x_{\eta}$ and bonds $b$ choose how much to consume, how many hours to work and how many bonds and reserves to take into the next loan market. Thereby, the real value of new bonds and reserves $\phi\left(m^{\prime}+b^{\prime}\right)$ plus the consumption $c$ has to equal the income of the bank, which consists of labor income $h$, and the return to its portfolio, where $i^{d}$ is the deposit interest rate, $i^{M}$ is the money market interest rate, $i^{b}$ is the bond interest rate, and $\eta f\left(\frac{\ell_{\eta}}{\kappa^{-}}\right)$is the return from loans made in the previous period.

Replacing the constraint into the value function yields

$$
\begin{aligned}
V^{S}\left(m+d-\ell_{\eta}-x_{\eta}, b\right)= & \phi m+\phi\left(1+i^{b}\right) b-\phi i^{d} d+\phi i^{M} x_{\eta}+\theta\left(\eta f\left(\frac{\ell_{\eta}}{\kappa^{-}}\right)-\phi \ell_{\eta}\right) \\
& +\max _{m^{\prime}, b^{\prime}}-\phi\left(m^{\prime}+b^{\prime}\right)+\mathbb{E}\left[V^{L}\left(m^{\prime}, b^{\prime}\right)\right] .
\end{aligned}
$$

Banks also set the interest rate on new deposits $i^{d}$ during the settlement market in order to attract capital producers. Capital producers then open accounts, but leave the settlement market without deposits as they only produce and get paid during the loan market. Note that banks leave the settlement market with equity as their only liability, as the reserves and collateral they bring 
to the loan market are financed either by withheld profits or by labor income. Banks can raise equity only during the settlement market, so while they might be willing to acquire additional reserves or collateral during the loan market, they are unable to do so because they cannot raise additional equity during that subperiod. Likewise, as banks can only set the interest rate on deposits during the settlement market, they cannot attract additional deposits during the loan market. This captures the idea that it takes time for banks to raise additional equity or deposits.

After paying back their loans, old entrepreneurs consume $(1-\theta)\left(\eta f\left(\frac{\ell_{\eta}}{\kappa^{-}}\right)-\phi \ell_{\eta}\right)$ during the settlement market. Capital producers use deposits they earned during the previous loan market to consume. Capital producers then open a new deposit account in order to be able to get paid with deposits during the next loan market, but these accounts remain empty until the beginning of the loan market. Young entrepreneurs are born during the settlement market and are randomly matched with a bank. Because they have no source of income, young entrepreneurs cannot accumulate funds during the settlement market. Capital producers would be willing to acquire fiat money if $\frac{\phi}{\phi^{+}}=\beta$ (i.e., the Friedman rule is prevalent), or if either $1+i^{d}$ or $1+i^{b}$ are equal to $\frac{\frac{\phi}{\phi}}{\beta}$ (i.e., an assets interest rate perfectly compensates the owner for inflation and discounting). At these rates, capital producers are willing to hold any amount of the respective assets ${ }^{8}$. For higher inflation and lower interest rates, respectively, capital producers leave the settlement market without any assets.

\subsection{The banks' problem}

By combining the banks' value functions from both subperiods, we obtain the following maximization problem:

$$
\begin{aligned}
& V(m, b)=\max _{\ell_{\eta}, x_{\eta}, m^{\prime}, b^{\prime}} \phi^{+} m+\phi^{+}\left(1+i^{b}\right) b-\phi^{+} i^{d} d+\phi^{+} i^{M} x_{\eta}+\theta\left(\eta f\left(\frac{\ell_{\eta}}{\kappa}\right)-\phi^{+} \ell_{\eta}\right) \\
& -\phi^{+}\left(m^{\prime}+b^{\prime}\right)+\beta \mathbb{E}\left[V\left(m^{\prime}, b^{\prime}\right)\right] \\
& \text { s.t. } m-\ell_{\eta} \leq(1-\delta I) x_{\eta}-(1-\delta) d \quad\left(\phi^{+} \lambda_{1}\right) \\
& \text { s.t. }-x_{\eta} \leq b \quad\left(\phi^{+} \lambda_{2}\right) \text {. }
\end{aligned}
$$

Solving this problem gives rise to the following first-order conditions:

\footnotetext{
${ }^{8}$ At higher rates, capital producers would be willing to hold an infinite amount of these assets, thus ensuring that the rate can never be higher in equilibrium.
} 


$$
\begin{aligned}
\ell_{\eta}: & 0=\theta\left(\frac{1}{\kappa} \eta f^{\prime}\left(\frac{\ell_{\eta}}{\kappa}\right)-\phi^{+}\right)+\phi^{+} \lambda_{1} \\
x_{\eta} \mid I=0: & i^{M}=-\lambda_{1} \\
x_{\eta} \mid I=1: & i^{M}=-\lambda_{1}(1-\delta)-\lambda_{2} \\
m^{\prime}: & \phi^{+}=\beta \mathbb{E}\left[V_{m}\left(m^{\prime}, b^{\prime}\right)\right] \\
b^{\prime}: & \phi^{+}=\beta \mathbb{E}\left[V_{b}\left(m^{\prime}, b^{\prime}\right)\right],
\end{aligned}
$$

and the envelope conditions are

$$
\begin{aligned}
& V_{m}(m, \eta)=\phi^{+}-\phi^{+} \lambda_{1} \\
& V_{m}(m, \eta)=\phi^{+}\left(1+i^{b}\right)+\phi^{+} \lambda_{2} .
\end{aligned}
$$

\section{Equilibrium}

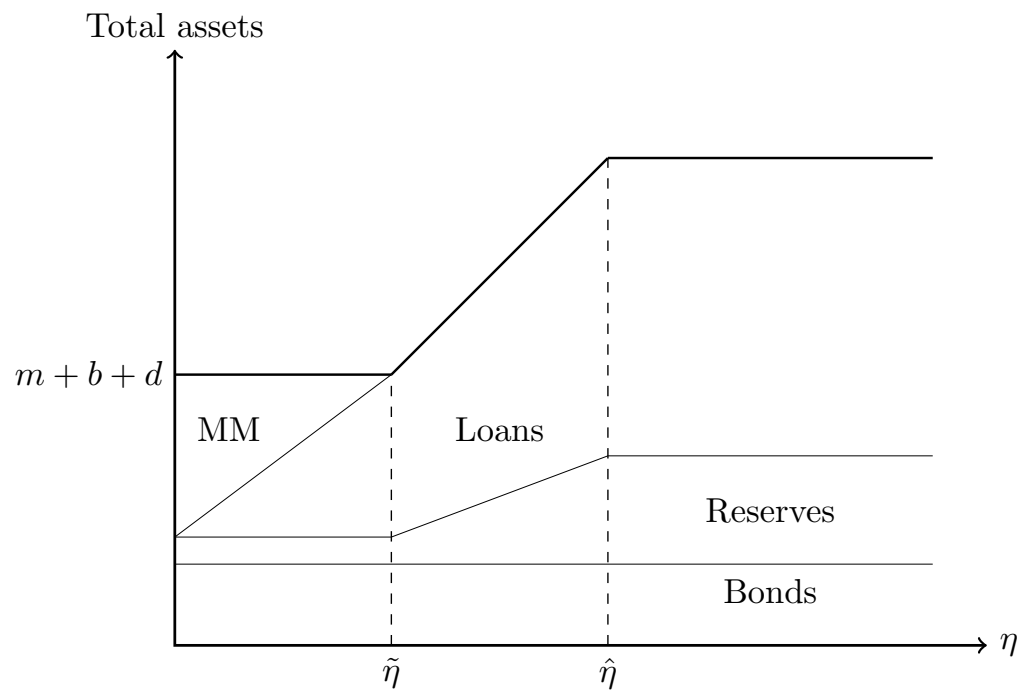

Figure 3: Banks' assets as a function of $\eta$.

There are two nonlinearities regarding the choice of loans granted in equilibrium. The first nonlinearity arises from the reserve requirement constraint, as net borrowers on the money market have to borrow additional reserves against their money market positions. The second nonlinearity arises from the collateral constraint. I denote the threshold value of $\eta$ that separates net lenders from net borrowers as $\tilde{\eta}$, such that banks with $\eta<\tilde{\eta}(\eta>\tilde{\eta})$ are net lenders (borrowers). The threshold above which banks are collateral constraint is denoted by $\hat{\eta}$. Figures 3 and 4 show the 


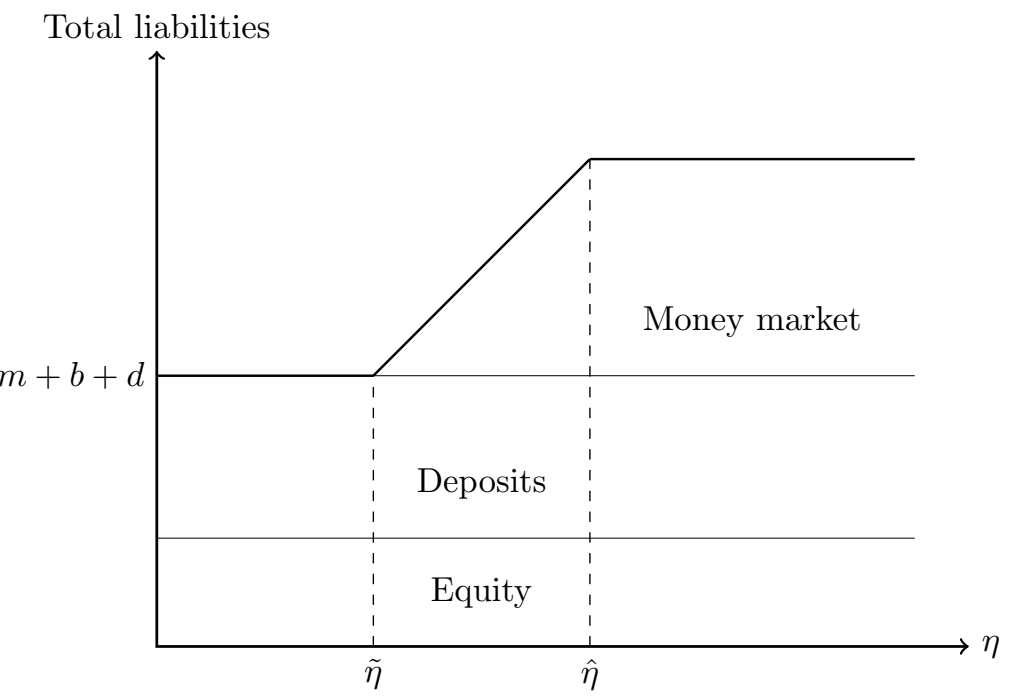

Figure 4: Banks' liabilities as a function of $\eta$.

asset and liabilities side of the banks' balance sheets at the end of the period as a function of the investment opportunity $\eta$.

To solve for the equilibrium of the model, we have to combine the first-order conditions with the market clearing conditions. By rearranging equation (8) and taking the expectation over $\lambda_{1}$, equations (11) and (13) can be combined and rewritten as

$$
\frac{1}{\beta}=(1-\theta) \frac{\phi^{+}}{\phi}+\frac{\theta}{\phi \kappa} \int_{0}^{\infty} \eta f^{\prime}\left(\frac{\ell_{\eta}}{\kappa}\right) \mathrm{d} G(\eta) .
$$

Equation (15) states that the decision of how many reserves to acquire in the settlement market depends on the banks' expectation over investment opportunities.

Similarly, by combining equations (8) and (10), taking expectations over $\lambda_{2}$, and plugging this into equations (12) and (14), the condition for acquiring bonds can be written as

$$
\frac{1}{\beta}=\frac{\phi^{+}}{\phi}\left(1+i^{b}\right)+(1-\delta) \frac{\theta}{\phi \kappa} \int_{\tilde{\eta}}^{\infty} \eta f^{\prime}\left(\frac{\ell_{\eta}}{\kappa}\right) \mathrm{d} G(\eta)-\frac{\phi^{+}}{\phi}\left((1-\delta) \theta+i^{M}\right) \int_{\tilde{\eta}}^{\infty} \mathrm{d} G(\eta) .
$$

Equation (16) states that the decision of how many bonds to acquire in the settlement market depends on the interest rate on bonds, and the banks' expectation over investment opportunities above $\tilde{\eta}$, as holding more bonds allows a bank to borrow more reserves and thus conduct higher investments in case it is a money market borrower.

By combining equation (8) with equation (9) (equation (10)), we can find the equilibrium 
conditions regarding bank lending for all banks that are money market lenders (unconstrained money market borrowers):

$$
\begin{aligned}
& \eta f^{\prime}\left(\frac{\ell_{\eta}}{\kappa}\right)=\phi^{+} \kappa\left(1+\frac{i^{M}}{\theta}\right) \quad \forall \eta \in(0, \tilde{\eta}) \\
& \eta f^{\prime}\left(\frac{\ell_{\eta}}{\kappa}\right)=\phi^{+} \kappa\left(1+\frac{i^{M}}{\theta(1-\delta)}\right) \quad \forall \eta \in(\tilde{\eta}, \hat{\eta}) .
\end{aligned}
$$

For banks that are collateral constrained, loans granted are given by

$$
\ell_{\eta}=m+(1-\delta)(d+b) \quad \forall \eta \in(\hat{\eta}, \infty) .
$$

From equation (18), it becomes clear that additional lending is more costly for a bank that is a net borrower on the money market, as the opportunity cost is not just the money market interest rate on the additional credit, but $\frac{1}{1-\delta}$ times the money market rate as these banks need to acquire additional funds and reserves. For banks that are collateral constrained, additional lending is not possible and thus their lending is independent of the realization of $\eta$.

The equations (9) and (10) show that the reserve requirement will be binding for all banks $\forall i^{M}>0$, so we have

$$
\begin{aligned}
& x_{\eta}=m-\ell_{\eta}+(1-\delta) d \quad \forall \eta \in(0, \tilde{\eta}) \\
& x_{\eta}=\frac{m-\ell_{\eta}}{1-\delta}+d \quad \forall \eta \in(\tilde{\eta}, \hat{\eta}) \\
& x_{\eta}=-b \quad \forall \eta \in(\hat{\eta}, \infty) .
\end{aligned}
$$

The threshold values $\tilde{\eta}$ and $\hat{\eta}$ can be found by stating the condition that gives a bank a zero net position on the money market, or that of a bank which exactly pledges all its collateral, respectively:

$$
\begin{aligned}
\tilde{\eta} f^{\prime}\left(\frac{1}{\kappa}(m+(1-\delta) d)\right) & =\phi^{+} \kappa\left(1+\frac{i^{M}}{\theta}\right) \\
\hat{\eta} f^{\prime}\left(\frac{1}{\kappa}(m+(1-\delta)(d+b))\right) & =\phi^{+} \kappa\left(1+\frac{i^{M}}{\theta(1-\delta)}\right) .
\end{aligned}
$$

To ensure market clearing, total deposits have to equal the sum of all loans, bonds purchased by banks have to equal bonds issued, and money market positions have to net to zero, such that

$$
\begin{aligned}
& 0=\int_{0}^{\infty} x_{\eta} \mathrm{d} G(\eta)+x^{C B} \\
& d=\int_{0}^{\infty} \ell_{\eta} \mathrm{d} G(\eta) \\
& b=B
\end{aligned}
$$


holds. In equation $25, x^{C B}$ denotes the money market position of the central bank. As explained above, I use $\iota^{M}$ to denote the money market rate in the absence of central bank borrowing or lending (i.e., for $\left.x^{C B}=0\right)$. If $\iota^{M}<i^{D}\left(\iota^{M}>i^{L}\right), i^{M}=i^{D}\left(i^{M}=i^{L}\right)$, and $x^{C B}<0\left(x^{C B}>0\right)$. Otherwise, $i^{M}=\iota^{M}$ and $x^{C B}=0$.

To pin down $i^{d}$, one can make an arbitrage argument. Instead of acquiring equity in the settlement market, a bank could deviate by offering an interest rate on deposits slightly higher than other banks, such that it accrues more deposits to make up for the equity. This deviation is profitable as long as deposits are cheaper to acquire than equity, which is true for any $i^{d}<\frac{1+\pi}{\beta}$. Therefore, the equilibrium interest rate on deposits is given by $i^{d}=\frac{1+\pi}{\beta}$.

Equations (15)-(27) show the mechanics of the model. However, the system can be reduced to 6 equations and 6 unknowns. The remaining unknowns after reducing the system are $\phi d, \phi m, i^{b}$, $i^{M}$, and the thresholds $\tilde{\eta}$ and $\hat{\eta}$, given equation (5) and $i^{d}=\frac{1+\pi}{\beta}$. Equations (23) and (24) are already written in only these variables, so they are part of the reduced system. The additional equations are

$$
\begin{aligned}
& \frac{1}{\beta}=(1-\theta) \frac{\phi^{+}}{\phi}+\frac{\phi^{+}}{\phi}\left(\left(\theta+i^{M}\right) \int_{0}^{\tilde{\eta}} \mathrm{d} G(\eta)+\left(\theta+\frac{i^{M}}{1-\delta}\right) \int_{\tilde{\eta}}^{\hat{\eta}} \mathrm{d} G(\eta)\right) \\
& +\frac{\theta}{\phi \kappa} f^{\prime}\left(\frac{1}{\kappa}(m+(1-\delta)(d+B))\right) \int_{\hat{\eta}}^{\infty} \eta \mathrm{d} G(\eta) \\
& \frac{d}{\kappa}=\int_{0}^{\tilde{\eta}} f^{\prime-1}\left(\phi^{+} \kappa\left(1+\frac{i^{M}}{\theta}\right) \frac{1}{\eta}\right) \mathrm{d} G(\eta)+\int_{\tilde{\eta}}^{\infty} f^{\prime-1}\left(\phi^{+} \kappa\left(1+\frac{i^{M}}{\theta(1-\delta)}\right) \frac{1}{\eta}\right) \mathrm{d} G(\eta) \\
& +\frac{1}{\kappa}(m+(1-\delta)(d+B)) \int_{\hat{\eta}}^{\infty} \mathrm{d} G(\eta) \\
& 0=\frac{1}{\kappa}\left[(m+(1-\delta) d) \int_{0}^{\tilde{\eta}} \mathrm{d} G(\eta)+\phi\left(\frac{m}{1-\delta}+d\right) \int_{\tilde{\eta}}^{\hat{\eta}} \mathrm{d} G(\eta)-B \int_{\hat{\eta}}^{\infty} \mathrm{d} G(\eta)\right]+\frac{x^{C B}}{\kappa} \\
& -\int_{0}^{\tilde{\eta}} f^{\prime-1}\left(\phi^{+} \kappa\left(1+\frac{i^{M}}{\theta}\right) \frac{1}{\eta}\right) \mathrm{d} G(\eta)-\frac{1}{1-\delta} \int_{\tilde{\eta}}^{\infty} f^{\prime-1}\left(\phi^{+} \kappa\left(1+\frac{i^{M}}{\theta(1-\delta)}\right) \frac{1}{\eta}\right) \mathrm{d} G(\eta) \\
& \frac{1}{\beta}=\frac{\phi^{+}}{\phi}\left(i+i^{b}\right)-\frac{\phi^{+}}{\phi}\left((1-\delta) \theta+i^{M}\right) \int_{\tilde{\eta}}^{\infty} \mathrm{d} G(\eta)+(1-\delta) \frac{\phi^{+}}{\phi}\left(\theta+\frac{i^{M}}{1-\delta} \int_{\tilde{\eta}}^{\hat{\eta}} \mathrm{d} G(\eta)\right) \\
& +(1-\delta) \frac{\theta}{\phi \kappa} f^{\prime}[\phi(m+(1-\delta)(d+B))] \int_{\hat{\eta}}^{\infty} \eta \mathrm{d} G(\eta) .
\end{aligned}
$$


Equation (28) is derived by integrating over equations (17) - (19) and then combining the result with equation (15). Equation (29) is derived by first inverting and then integrating equations (17) - (19) and then making use of equation (26). Equation (30) is derived by integrating equations (20) - (22), inverting equations (17) and (18), and making use of equation (25). Equation (31) is derived by combining equations (18) and (19) with (16). I also made use of equation (27) throughout.

In steady state, all real variables stay constant over time, which implies that the quantity theory of money holds. Thus, the inflation rate is given by $\gamma=1+\pi=\frac{\phi}{\phi^{+}}$. Now, a steady-state equilibrium can be defined:

Definition 1. A steady-state equilibrium is defined by the quantities $\phi m$ and $\phi d$, threshold values $\tilde{\eta}$ and $\hat{\eta}$, and the interest rates $i^{b}$, and $i^{M}$, that simultaneously solve the equations (23), (24), and (28)-(31) for $i^{D} \leq i^{M} \leq i^{L}$ and $x^{C B}=0$, or $i^{M}=i^{D}$ and $x^{C B}<0$, or $i^{M}=i^{L}$ and $x^{C B}>0$,.

After solving the system, $x_{\eta}$ and $\ell_{\eta} \forall \eta$ can be backed out again by using equations (17)-(22).

\subsection{Welfare}

As stated in section 2.1, the first-best investment for each bank is given by $\eta f^{\prime}\left(\frac{\ell_{\eta}}{\kappa}\right)=\frac{1}{\beta}$. From equations (17)-(19), we get the actual investment given $\eta$. It can easily be seen that marginal return on investment differs across the three types of banks (money market lenders, unconstrained money market borrowers, and constrained money market borrowers), although marginal return is equal across banks at the first-best. Money market lenders face the lowest financing costs, so they choose the lowest marginal return on investment, unconstrained money market borrowers choose a higher marginal return on investment due to higher financing costs, and constrained money market borrowers all undertake the same amount of investment although their investment return differs. It can also be seen that marginal return on investment is increasing in $\theta$, showing that lower bargaining power for banks decreases investment. This shows that financial frictions inside and outside the banking system have distorting effects on welfare. For high $\theta$, banks that are net lenders on the money market might overinvest compared to the first-best. Otherwise, all banks are investing less than what would be optimal.

Figure 5 shows the marginal return on investment as a function of $\eta$ and compares it with the first-best. I used the parameter values stated in table 1 to produce this figure. The figure shows that banks that are hit with a low $\eta$ invest the most on the margin, while banks with the highest $\eta$ invest much less than would be ideal. 


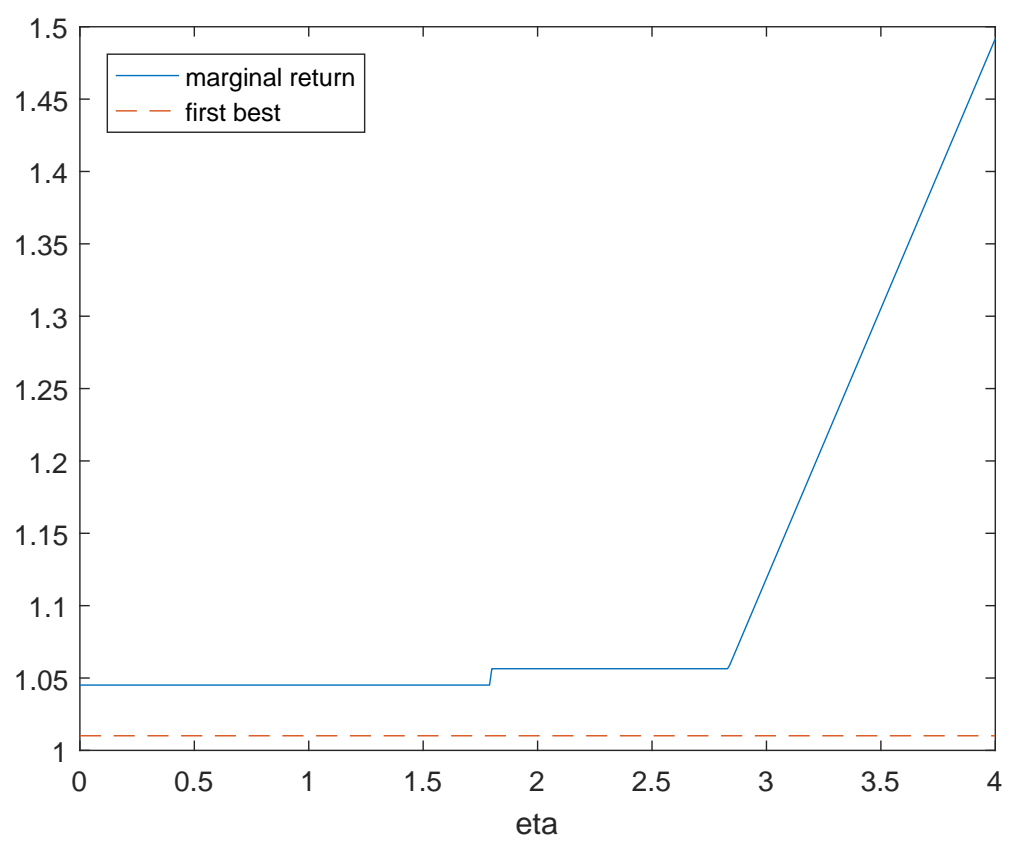

Figure 5: Marginal return on investment as a function of $\eta$.

\section{Policy}

In this section, I analyze the effects of different monetary policies on interest rates, investment, and output numerically. The policies analyzed are changes in the money growth rate, changes in the reserve requirement, open market operations, and the channel system. I want to assess first whether these policies can be used to affect interest rates, and then whether using a specific tool to lower interest rates leads to an increase in bank lending and thus investment, as predicted by the conventional wisdom. I will report the return on investment (output), instead of investment itself, as this is more relevant for welfare. However, because overinvestment never occurs for the parameters I chose, increases in output always come from increases in investment. The policy analysis will show that there are two main effects from varying the money market interest rate: There is a direct effect that increases lending of all banks that are not collateral-constrained, as can be seen in equations (17) and (18), but also an indirect effect through the aggregate amount of reserves banks acquire ex-ante. High money market interest rates make it attractive to lend out reserves in the case that a bank is hit with a low $\eta$. This outside option makes it more attractive for banks to self-insure against being collateral-constrained by acquiring more reserves ex-ante, which then leads to fewer collateral-constrained banks on aggregate. An effective policy thus has to lower interest rates without distorting the efficiency of this self-insurance.

I assume the following functional forms: $f(k)=A k^{\varphi}$, and $G(\eta)$ being lognormally distributed 
with mean parameter $\mu$ and variance parameter $\sigma$. If not stated otherwise, I use the parameter values for the exogenous variables listed in table 1 . These parameter values ensure interior solutions for all the policy experiments I conduct. For all the parameter values I tried, results didn't change qualitatively as long as the solutions for all endogenous variables were interior. Potential corner solutions are: $i^{M}$ or $i^{b}$ hitting zero or the Fisher equation interest rate $\left(\frac{1+\pi}{\beta}\right)$, or ex-ante reserve holdings being zero. In each of these cases, equilibrium either doesn't exist at all, or the equilibrium equations differ from the ones stated above. I thus focus on interior solutions for the remainder of the paper.

\begin{tabular}{lc}
\hline Parameter & value \\
\hline \hline$\beta$ & 0.99 \\
\hline$\gamma$ & 1.06 \\
\hline$\delta$ & 0.1 \\
\hline$\theta$ & 0.6 \\
\hline $\mathcal{B}$ & 2 \\
\hline$i^{D}$ & 0 \\
\hline$i^{L}$ & 0.5 \\
\hline$A$ & 1.3 \\
\hline$\varphi$ & 0.5 \\
\hline$\mu$ & 0.5 \\
\hline$\sigma$ & 0.3 \\
\hline
\end{tabular}

Table 1: Parameter values for exogenous variables.

\subsection{Money growth rate}

The monetary authority can set the money growth rate by adjusting $\gamma$. In steady state, increasing the money growth rate directly increases inflation. Figure 6a shows the effect on bond and money market interest rates of increasing inflation from 0 to 20 percent, which corresponds to an increase of $\gamma$ from 1 to 1.2. As can be seen in the figure, both interest rates increase with inflation. So if the monetary authority wants to lower the money market rate via the money growth rate, it can do so by lowering the money growth rate. Figure $6 \mathrm{~b}$ shows the effect of a change in the money growth rate on output, which is the return on investment. The figure shows that increasing the money growth rate lowers output. This is because higher inflation means that banks face higher costs to hold the required reserves. While banks are able to lend excess reserves on the money 


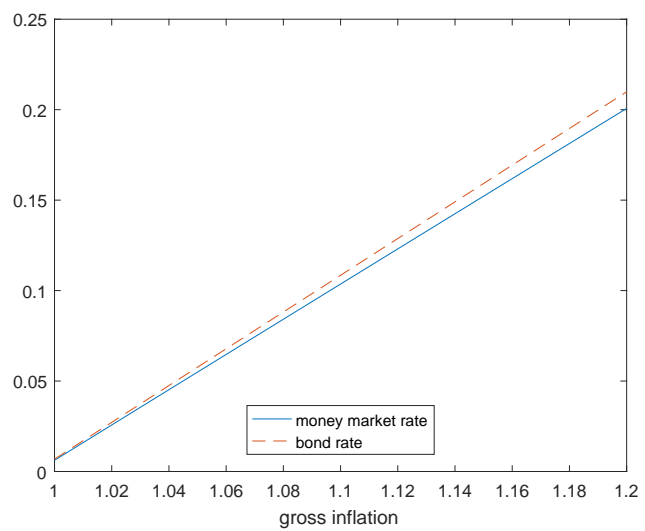

(a) Interest rates.

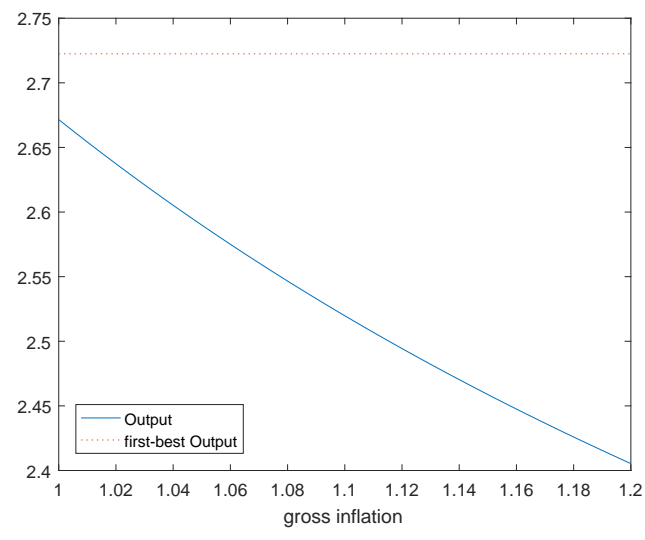

(b) Output.

Figure 6: The effect of an increase in money growth on interest rates and output.

market for an interest rate that compensates for inflation, the required reserves cannot be lent out, so banks have to pay the inflation tax on them. Therefore, they acquire less reserves in real terms ex-ante at higher inflation rates. So if the central bank lowers the money growth rate, it achieves a decrease in interest rates and an increase in output, just as predicted by the conventional wisdom.

\subsection{Reserve requirement}

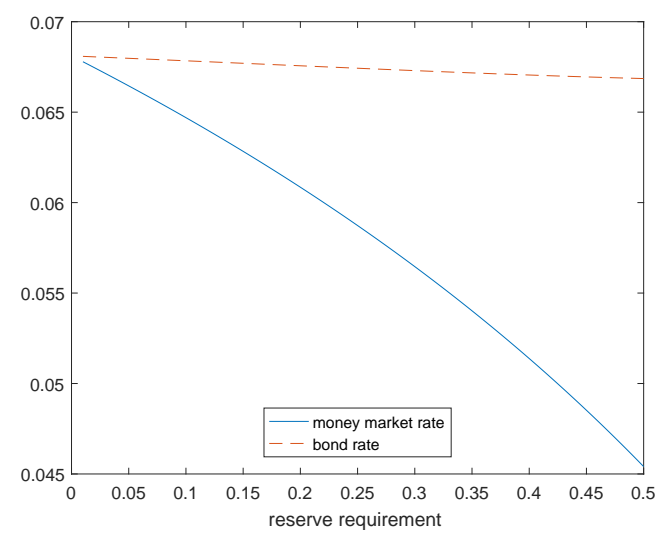

(a) Interest rates.

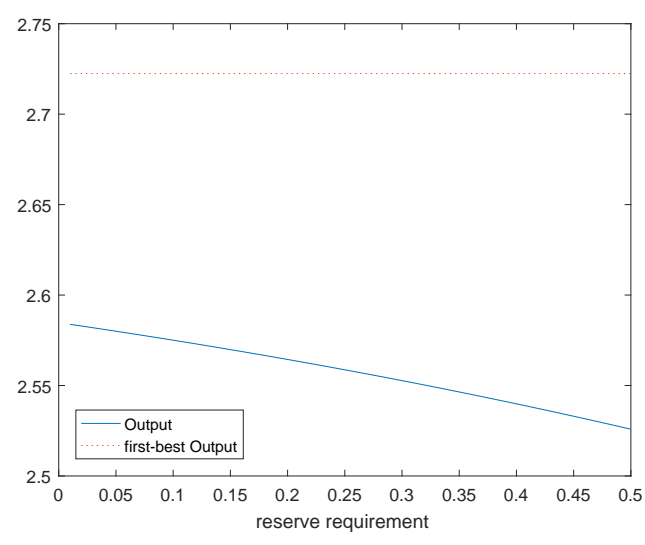

(b) Output.

Figure 7: The effect of an increase in the reserve requirement on interest rates and output.

The monetary authority can adjust the reserve requirement by changing $\delta$. The reserve requirement has to be positive to ensure demand for fiat money ${ }^{9}$. Therefore, I am studying an increase

\footnotetext{
${ }^{9}$ For a justification as to why reserve requirements are implemented by central banks, see Monnet and Sanches (2015).
} 
of $\delta$ from 0.01 to 0.5. The effect of such an increase on interest rates can be seen in Figure 7a. As explained in Section 4.1, banks have to pay the inflation tax on required reserves. Thus, an increase in the reserve requirement makes it more costly for banks to fund loans. An increase in the reserve requirement also makes it more expensive to be a borrower on the money market, as the money market borrowers have to acquire additional reserves against the money market positions, and that wedge becomes more important for higher $\delta$. This makes collateral effectively more scarce, as the required collateral increases with the amount of reserves banks have to borrow. Therefore, the interest rate on bonds decreases with an increase in the reserve requirement as all banks try to hold more collateral. Due to the reduced borrowing capacities of banks that draw a high $\eta$, banks acquire more reserves ex-ante ${ }^{10}$, so demand on the money market decreases while supply increases, which leads to the fall in the money market interest rate.

As an increase in the reserve requirement leads to a decrease in the money market rate, conventional wisdom would suggest that such an increase also leads to an increase in investment and output. However, Figure $7 \mathrm{~b}$ shows that this is not the case. Instead, investment and output are decreasing with increases in the reserve requirement. The decrease in the money market interest rate that follows from an increase in the reserve requirement makes money market lenders invest more, and there are actually more money market lenders due to the fact that $\tilde{\eta}$ is increasing in $\delta$. Overall investment still goes down, however, as money market borrowers invest less, and the share of collateral-constrained banks increases because $\hat{\eta}$ is decreasing in $\delta$.

\subsection{Open market operations}

By issuing fiat money against government bonds, or by selling government bonds for fiat money, the monetary authority can perform open market operations. These open market operations have an effect on the economy by altering the real amount of bonds that can be used as collateral by banks. To analyze the effect of open market operations, I vary the bond supply that is available to banks. I assume here that open market operations are performed during the settlement market. Figure 8a shows that a higher bond supply (corresponding to open market sales of bonds) implies higher interest rates. For the interest rate on bonds, this is straightforward: A higher bond supply lowers the pressure on prices, which means that the inverse of bond prices, i.e., the bond interest rate, increases. The money market interest rate increases with the bond supply because more collateral available makes it easier to borrow reserves on the money market, which means borrowing has to become more expensive to ensure equality of demand and supply, which is achieved by an increase

\footnotetext{
${ }^{10}$ Even on top of the fact that they directly need more reserves due to the increase in $\delta$; this overcompensation is captured by an increase in $\tilde{\eta}$.
} 


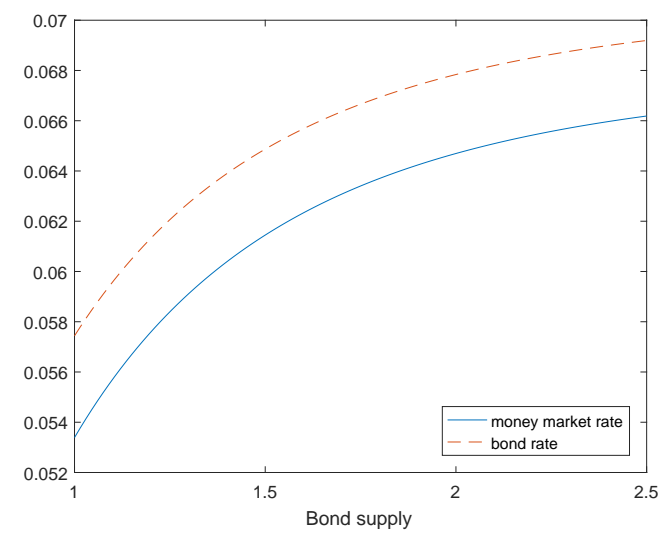

(a) Interest rates.

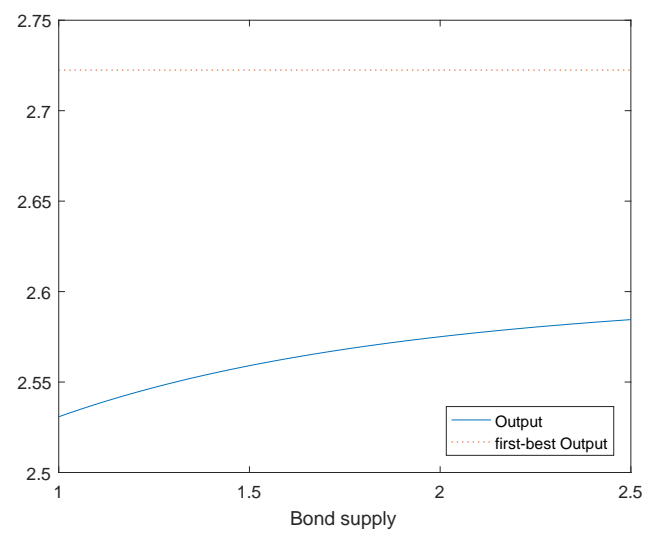

(b) Output.

Figure 8: The effect of open market operations on interest rates and output.

in the money market interest rate.

Figure $8 \mathrm{~b}$ shows that the conventional wisdom does not hold up in the case of open market operations either. While open market purchases of bonds decrease the money market interest rate, they also lead to less investment and output. This is because such purchases make collateral more scarce, making it harder to borrow reserves on the money market and increasing the number of collateral-constrained banks. This happens for two reasons: There is a direct effect that results from lowering the collateral available and thus lowering the overall capacity for the market to borrow; but also an indirect effect that operates by making it less attractive to lend out reserves if hit by a low $\eta$, as there are less banks that are able to borrow. This indirect effect prevents banks from acquiring more reserves ex-ante in order to insure against being collateral-constrained. This analysis shows that the monetary authority should use open market sales of collateral if it wants to spur investment.

\subsection{Channel system}

By choosing deposit and lending rates $i^{D}$ and $i^{L}$ such that the equilibrium money market rate lies outside of the channel, the monetary authority can force the money market rate $i^{M}$ to increase or decrease. As can be seen in table 1, the baseline values for the channel rates are such that they are irrelevant given the other parameters, in order to be able to analyze the effects of the other policy tools in isolation. In this section, I am analyzing the effects of binding channel rates. Figure 9a shows the effect of lowering the central bank's lending rate $i^{L}$ on the other interest rates. As long as the lending rate is above the equilibrium money market rate, lowering it has no effect. Once it is below the equilibrium rate, the money market rate equals the central bank's lending rate. 


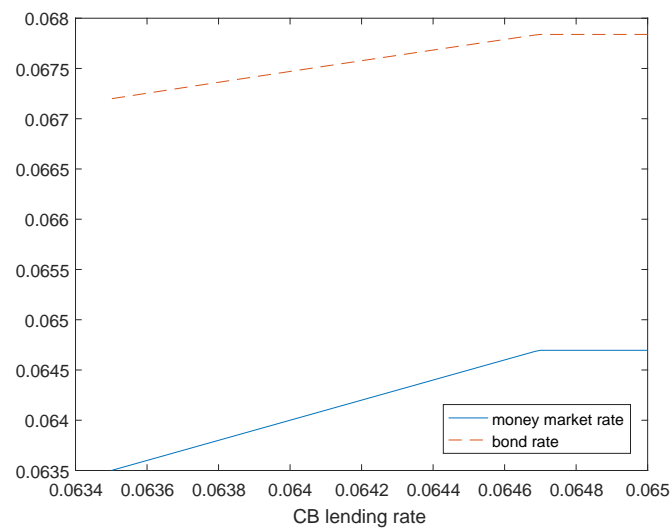

(a) Interest rates as a function of $i^{L}$.

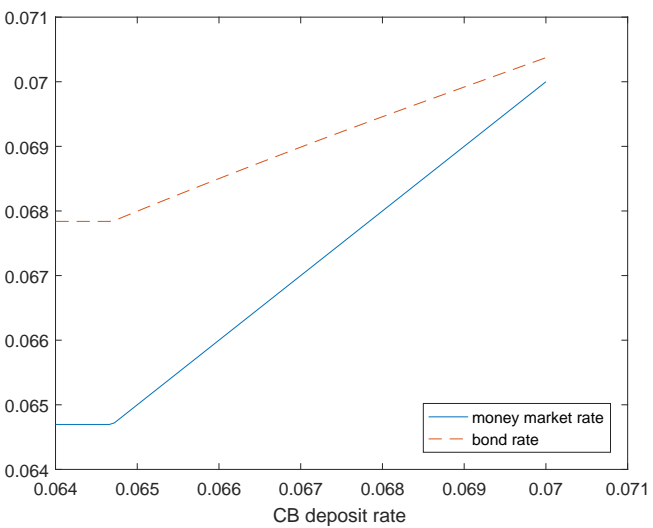

(c) Interest rates as a function of $i^{D}$.

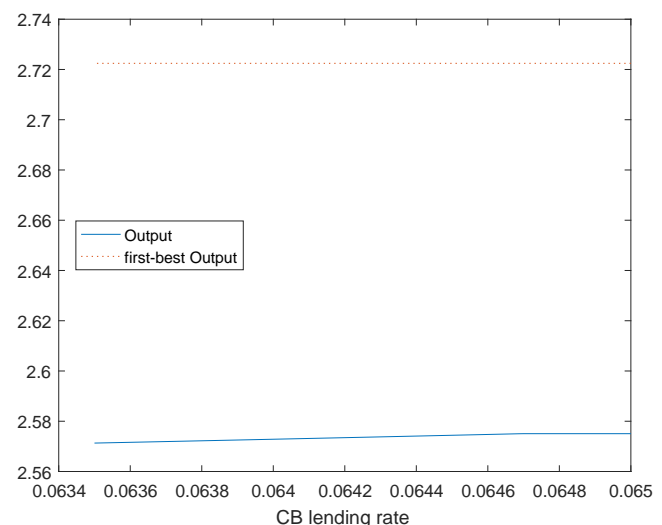

(b) Output as a function of $i^{L}$.

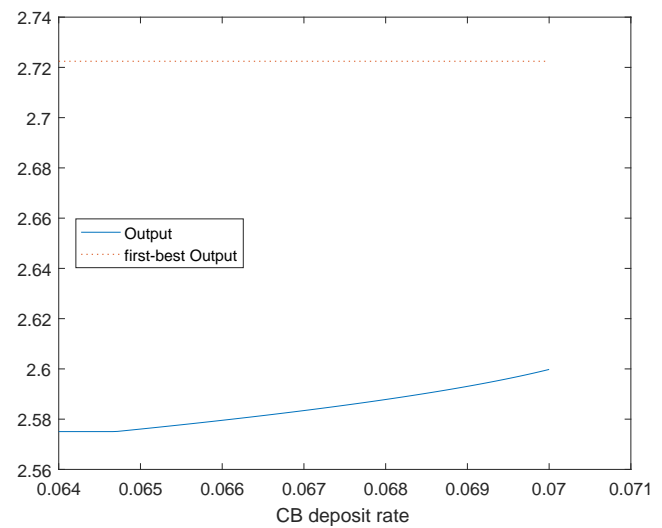

(d) Output as a function of $i^{D}$.

Figure 9: The effect of changes in the channel system on interest rates and output.

The bond interest rate also decreases with the money market rate, as the lower money market rate makes borrowing reserves more attractive, thus increasing the demand for bonds and in turn lowering interest rates. Another thing to be noted is the small scope of the intervention: It is possible to lower the money market rate from about 0.0647 percent to 0.0635 percent. It cannot be lowered further however, as that would stop banks from acquiring any reserves ex-ante and thus eliminate the money demand completely. This shows that the channel system can only affect the money market interest rate to a limited extent. Figure 9c shows that the central bank can increase the money market rate by increasing the central bank deposit rate $i^{D}$. The mechanisms at work are just the inverse of what happens after lowering the lending rate. Again, the scope of the policy is limited: The deposit rate cannot only be set such that $1+i^{D} \leq \frac{1+\pi}{\beta}$. If the deposit rate is set higher, it exceeds the cost of holding reserves, which means that banks would want to acquire an infinity of reserves.

Figures $9 \mathrm{~b}$ and $9 \mathrm{~d}$ show the reaction of output to changes in the money market rate through 
the channel system. Again, lowering the money market rate does not have the desired effect of increasing investment and output. Instead, increasing the money market rate via increases in the deposit rate leads to an increase in output. The reason is the indirect effect on reserve acquisition described earlier: By offering a lending rate that is below the market equilibrium rate, the central bank makes it less attractive for banks to acquire reserves ex-ante, as borrowing becomes cheaper, and lending out the reserves in the case of being hit by a low $\eta$ becomes less profitable. But if all banks acquire less reserves ex-ante, this increases the share of banks that end up being collateral constrained, thus reducing overall investment. By increasing the money market rate via the central bank's deposit rate, just the opposite happens. Gaining the ability to deposit reserves at a higher than market interest rate at the central bank induces banks to acquire more reserves ex-ante, thereby reducing the share of banks that end up being collateral constrained. While this policy lowers investment on the margin by unconstrained banks, the reduction in the share of constrained banks is large enough to make overall investment increase.

\section{Conclusion}

This paper shows that the frictions inside the banking system can have counterintuitive effects on the transmission mechanism of monetary policy. While the central bank has many tools at its disposal that can be used to lower the money market interest rate, applying these tools also changes banks' incentives to self-insure themselves against ending up collateral-constrained. This latter effect arises because low lending rates in the money market make it less attractive to acquire reserves ex-ante instead of borrowing them ex-post. But since borrowing ex-post requires collateral, increasing the share of money market borrowers also increases the share of collateral-constrained banks. In the numerical analysis I conducted, the latter effect dominates, which means that lowering the money market rate relative to the inflation rate lowers investment and output.

\section{Bibliography}

Altermatt, L. (2017). Inside money, investment, and unconventional monetary policy. University of Zurich, Department of Economics Working Paper No. $24 \%$.

Arce, O., Nuno, G., Thaler, D., and Thomas, C. (2018). A large central bank balance sheet? the role of interbank market frictions. mimeo.

Berentsen, A., Camera, G., and Waller, C. (2007). Money, credit and banking. Journal of Economic Theory, 135 (1):171-195. 
Berentsen, A., Kraenzlin, S., and Mueller, B. (2015). Exit strategies and trade dynamics in repo markets. Working Paper.

Berentsen, A., Marchesiani, A., and Waller, C. (2014). Floor systems for implementing monetary policy: Some unpleasant fiscal arithmetic. Review of Economic Dynamics, 17:523-542.

Berentsen, A. and Monnet, C. (2008). Monetary policy in a channel system. Journal of Monetary Economics, 55:1067-1080.

Bianchi, J. and Bigio, S. (2017). Banks, liquidity management and monetary policy. NBER Working Paper 20490.

Brunnermeier, M. K., Eisenbach, T. M., and Sannikov, Y. (2012). Mmacroeconomics with financial frictions: A survey. NBER Working Paper 18102.

Brunnermeier, M. K. and Koby, Y. (2017). The "reversal interest rate": An effective lower bound on monetary policy. mimeo.

Diamond, D. W. and Dybvig, P. H. (1983). Bank runs, deposit insurance, and liquidity. Journal of Political Economy, 91 (3):401-419.

Faure, S. and Gersbach, H. (2017). Money creation and destruction. CEPR Discussion Paper 11368.

Gertler, M. and Karadi, P. (2011). A model of unconventional monetary policy. Journal of Monetary Economics, 58:17-34.

Gu, C., Mattesini, F., Monnet, C., and Wright, R. (2013). Banking: A new monetarist approach. The Review of Economic Studies, 80(2):636-662.

Lagos, R. and Wright, R. (2005). A unified framework for monetary theory and policy analysis. Journal of Political Economy, 113 (3):463-484.

Monnet, C. and Sanches, D. R. (2015). Private money and banking regulation. Journal of Money, Credit and Banking, 47(6):1031-1062.

Piazzesi, M. and Schneider, M. (2018). Payments, credit and asset prices. BIS Working Papers No 734 .

Rocheteau, G., Wright, R., and Zhang, C. (2018). Corporate finance and monetary policy. American Economic Review, 108(4-5):1147-1186.

Williamson, S. (2012). Liquidity, monetary policy, and the financial crisis: A new monetarist approach. American Economic Review, 102 (6):2570-2605. 